Marquette University

e-Publications@Marquette

Biomedical Sciences Faculty Research and

Publications

Biomedical Sciences, Department of

$2-1-2007$

$\beta$-N-methylamino-L-alanine Enhances

Neurotoxicity Through Multiple Mechanisms

Doug Lobner

Marquette University, doug.lobner@marquette.edu

Peachy Mae T. Piana

Marquette University

Abed K. Salous

Marquette University

Robert W. Peoples

Marquette University, robert.peoples@marquette.edu

Accepted version. Neurobiology of Disease, Vol. 25, No. 2 (February 2007): 360-366. DOI. (C) 2007 Elsevier. Used with permission. 


\title{
$\beta$-N-Methylamino-L-Alanine Enhances Neurotoxicity through Multiple Mechanisms
}

\author{
Doug Lobner \\ Department of Biomedical Sciences University \\ Marquette University \\ Milwaukee, WI \\ First M. Last \\ Department of Biomedical Sciences University \\ Marquette University \\ Milwaukee, WI \\ First M. Last \\ Department of Biomedical Sciences University \\ Marquette University \\ Milwaukee, WI \\ First M. Last \\ Department of Biomedical Sciences University \\ Marquette University \\ Milwaukee, WI
}

\section{Abstract}

The idea that the environmental toxin $\beta$ - $\mathrm{N}$-methylamino-L-alanine (BMAA) is involved in neurodegenerative diseases on Guam has risen and

Neurobiology of Disease, Vol. 25, No. 2 (February 2007): pg. 360-366. DOI. This article is (C) Elseiver and permission has been granted for this version to appear in e-Publications@Marquette. Elsevier does not grant permission for this article to be further copied/distributed or hosted elsewhere without the express permission from Elsevier. 
NOT THE PUBLISHED VERSION; this is the author's final, peer-reviewed manuscript. The published version may be accessed by following the link in the citation at the bottom of the page.

fallen over the years. The theory has gained greater interest with recent reports that BMAA is biomagnified, is widely distributed around the planet, and is present in the brains of Alzheimer's patients in Canada. We provide two important new findings. First, we show that BMAA at concentrations as low as $10 \mu \mathrm{M}$ can potentiate neuronal injury induced by other insults. This is the first evidence that BMAA at concentrations below the $\mathrm{mM}$ range can enhance death of cortical neurons and illustrates potential synergistic effects of environmental toxins with underlying neurological conditions. Second, we show that the mechanism of BMAA toxicity is three fold: it is an agonist for NMDA and mGluR5 receptors, and induces oxidative stress. The results provide further support for the hypothesis that BMAA plays a role in neurodegenerative diseases.

Keywords: BMAA, Alzheimer's disease, oxidative stress, apoptosis, necrosis, NMDA

\section{Introduction}

The hypothesis that BMAA is involved in the development of amyotrophic lateral sclerosis/Parkinson-dementia complex (ALS/PDC) on Guam, locally known as Lytico-Bodig, has risen and fallen since its initial proposal in 1987 (Spencer et al., 1987; Cox and Sacks, 2002). A major criticism regarding the hypothesis is that high BMAA concentrations are required to induce behavioral abnormalities and neuronal death. The initial proposal was that the native Chamorro people of Guam were exposed to BMAA through the consumption of cycad seeds containing BMAA. However, it was determined that the Chamorros thoroughly wash the cycad seeds leading to very low levels of BMAA being consumed (Duncan et al., 1990). Recent reports have brought the BMAA hypothesis back into prominence. First, it was shown that BMAA is biomagnified as it travels through the food chain from the cyanobacteria symbionts on cycad plants, to the fruit bats that forage on the cycad seeds, to the people who eat the bats (Cox et al., 2003). This is not the first instance of biomagnification of an excitotoxin; the consumption of shellfish that feed on algae that produce the excitotoxin domoic acid has led to human neurological deficits (Perl et al., 1990). Second, BMAA can become proteinassociated, leading to further increases in human BMAA levels and providing a potential mechanism for slow release (Murch et al., 2004). There is also previous evidence that many non-protein amino acids can become protein-associated (Rosenthal, 1977). The slow release of

Neurobiology of Disease, Vol. 25, No. 2 (February 2007): pg. 360-366. DOI. This article is @ Elseiver and permission has been granted for this version to appear in e-Publications@Marquette. Elsevier does not grant permission for this article to be further copied/distributed or hosted elsewhere without the express permission from Elsevier. 
BMAA provides a possible explanation for the delayed onset of ALS/PDC following the time of probable BMAA consumption (Ince and Codd, 2005). Third, BMAA has been found in cyanobacteria present throughout the world (Cox, 2005), suggesting that BMAA may be of concern not only for specific groups of Pacific Islanders, but for a much larger population. This point was further emphasized by the finding that BMAA is found not only in brain samples of ALS/PDC patients from Guam, but also in Alzheimer's disease patients from Canada (Murch et al., 2004). Questions regarding the BMAA hypothesis still remain. For example, a recent report found no evidence of BMAA in brains of patients with ALS/PDC or Alzheimer's disease (Montine et al., 2005). A number of technical differences may account for the differing results. Murch et al. (2004) used paraformaldehyde fixed tissue and performed an acid hydrolysis to release protein associated BMAA. While they found some free BMAA, the large majority of BMAA was protein associated. Montine et al. (2005) used non-fixed brain tissue. However, they did not perform an acid hydrolysis. A definitive answer will clearly require additional studies.

A critical problem with the BMAA theory at present is that even though biomagnification of BMAA in the environment can occur it is still not clear that high enough concentrations are reached to cause toxicity. Studies in cortical cell culture have shown that very high BMAA concentrations $(1-3 \mathrm{mM})$ are required to induce neuronal death (Ross et al., 1987; Weiss and Choi, 1988; Weiss et al., 1989). The purpose of the current studies was to test whether lower concentrations of BMAA could potentiate low level toxicity induced by other insults. The idea being that while BMAA alone may not cause neurological deficits, the combination of low level BMAA and naturally occurring insults, or genetic predisposition to various diseases, may lead to the expression of neurological diseases.

\section{Material and Methods}

\section{Materials}

Timed pregnant Swiss Webster mice were obtained from Charles River Laboratories (Wilmington, DE, USA). ${ }^{45} \mathrm{Ca}^{++}$was from PerkinElmer Life and Analytical Sciences (Boston, MA). 5-(and -6)- 
carboxy-2'7'-dichlorodihydrofluorescein diacetate (carboxy- $\mathrm{H}_{2}$ DCFDA) was from Molecular Probes (Eugene, OR). All other chemicals were obtained from Sigma (St. Louis, MO).

\section{Cortical cell cultures}

Timed pregnant Swiss Webster mice were obtained from Charles River Laboratories (Wilmington, DE, USA). Mixed cortical cell cultures containing neurons and astrocytes were prepared from fetal (15-16 day gestation) mice as previously described (Lobner, 2000). Dissociated cortical cells were plated on 24 well plates coated with poly-D-lysine and laminin in Eagles' Minimal Essential Medium (MEM, Earle's salts, supplied glutamine-free) supplemented with $5 \%$ heatinactivated horse serum, 5\% fetal bovine serum, $2 \mathrm{mM}$ glutamine, 26 $\mathrm{mM} \mathrm{NaHCO}$ and glucose (total $21 \mathrm{mM}$ ). Cultures were maintained in humidified $5 \% \mathrm{CO} 2$ incubators at $37^{\circ} \mathrm{C}$. The mice were handled in accordance with a protocol approved by the institutional animal care committee.

\section{Induction of neuronal death}

All experiments were performed on mixed cultures 13-15 days in vitro (DIV). Toxicity was induced by exposure to the toxic agents for 24 hours in media as described for plating except without serum. Amyloid- $\beta$ was prepared as a $1 \mathrm{mM}$ peptide stock solution in sterile distilled water and maintained for 3 days at room temperature to allow polymerization (Yin et al., 2006). In kainate, Fe, and BSO toxicity experiments, $1 \mu \mathrm{M}$ MK-801 was added to eliminate the effect of endogenously released glutamate acting on NMDA receptors. This procedure allows for the study of pure AMPA/kainate receptor mediated toxicity and pure oxidative stress induced toxicity without the confounding effects of NMDA receptor activation (Dugan et al., 1997). All exposure media contained 20-26 $\mathrm{mM} \mathrm{NaHCO}_{3}$, as it has been shown previously that $\mathrm{HCO}_{3}{ }^{-}$is required for expression of NMDA receptor mediated BMAA toxicity (Weiss and Choi, 1988).

Neurobiology of Disease, Vol. 25, No. 2 (February 2007): pg. 360-366. DOI. This article is @ Elseiver and permission has been granted for this version to appear in e-Publications@Marquette. Elsevier does not grant permission for this article to be further copied/distributed or hosted elsewhere without the express permission from Elsevier. 


\section{LDH Release}

Cell death was assessed in mixed cultures by the measurement of lactate dehydrogenase (LDH), released from damaged or destroyed cells, in the extracellular fluid 24 hours after the beginning of the insult. Blank LDH levels were subtracted from insult LDH values and results normalized to $100 \%$ neuronal death caused by $500 \mu \mathrm{M}$ NMDA. Control experiments have shown previously that the efflux of LDH occurring from either necrotic or apoptotic cells is proportional to the number of cells damaged or destroyed (Koh and Choi, 1987; Lobner, 2000). In none of the conditions in the studies presented here was there any evidence of glial cell death observed (assessed by trypan blue staining). Therefore results are presented as percent neuronal death.

\section{${ }^{45} \mathrm{Ca}^{++}$accumulation}

Mixed cortical cultures were exposed to BMAA or NMDA in the presence of ${ }^{45} \mathrm{Ca}^{++}$(final activity, $2 \mu \mathrm{Ci} / \mathrm{ml}$ ) for 1 hour (Harley et al., 1993). There was less than $10 \%$ neuronal death after the 1 hour exposure to the toxins as measured by LDH release. Exposure was terminated by thoroughly washing the cells of extracellular ${ }^{45} \mathrm{Ca}^{++}$. Subsequently, the extracellular media was removed, cells were lysed with $1 \%$ sodium dodecyl sulfate, and an aliquot was added to scintillation fluid for counting. Values were normalized to control ${ }^{45} \mathrm{Ca}^{++}$ uptake (60 minute exposure to ${ }^{45} \mathrm{Ca}^{++}$without BMAA or NMDA).

\section{Electrophysiological recording}

Whole-cell patch-clamp recording was performed as previously described (Ren et al., 2003). Briefly, gigaohm seals were obtained with patch electrodes (series resistance: 2 - $10 \mathrm{M} \Omega$, compensation 80\%), and cells were voltage-clamped at $-50 \mathrm{mV}$ and superfused in extracellular solution containing (in $\mathrm{mM}$ ): $\mathrm{NaCl}, 150 ; \mathrm{KCl}, 5 ; \mathrm{CaCl}_{2}$, 0.2 ; HEPES, $10 ; \mathrm{NaHCO}_{3}$, 20; glucose, 10; and sucrose, 10; $\mathrm{pH} 7.4$. The patch pipet solution contained (in $\mathrm{mM}$ ): $\mathrm{CsCl}, 140 ; \mathrm{Mg}_{4} \mathrm{ATP}, 2$; BAPTA, 10; HEPES, $10 ; \mathrm{NaHCO}_{3}, 20 ; \mathrm{pH}$ 7.4. Drugs were prepared daily in extracellular solution. Drug solutions were applied to cells from a multibarrel array of $600 \mu \mathrm{m}$ i.d. square glass tubing held in a stepper

Neurobiology of Disease, Vol. 25, No. 2 (February 2007): pg. 360-366. DOI. This article is @ Elseiver and permission has been granted for this version to appear in e-Publications@Marquette. Elsevier does not grant permission for this article to be further copied/distributed or hosted elsewhere without the express permission from Elsevier. 
motor-driven rapid solution exchange apparatus (Fast-step, Warner Instrument Co.). Data were filtered at $2 \mathrm{kHz}$ (low-pass, eight-pole Bessel) and acquired at $5-10 \mathrm{kHz}$ on a computer using a DigiData interface and pClamp software (Axon Instruments).

\section{Assay of intracellular oxidative stress}

Oxidative stress was assayed by measuring dichlorofluorescein oxidation using a fluorescent plate reader following a modification of a previous method (Wang and Joseph, 1999). Cultures were exposed to 3 mM BMAA for 3 hours in the presence of 5-(and -6)-carboxy-2'7'dichlorodihydrofluorescein diacetate (carboxy- $\mathrm{H}_{2}$ DCFDA) $(10 \mu \mathrm{M})$. There was less than $10 \%$ neuronal death after the 3 hour exposure to BMAA as measured by $\mathrm{LDH}$ release $(8.2 \pm 1.8 \%$ neuronal death measured at the end of 3 hour exposure to 3 mM BMAA). The carboxy$\mathrm{H}_{2}$ DCFDA is de-esterfied within cells to form a free acid that can then be oxidized to the fluorescent $2^{\prime} 7^{\prime}$-dichlorofluorescein (DCF). After the exposure to carboxy- $\mathrm{H}_{2}$ DCFDA, cultures were washed 3 times with culture media lacking serum. Fluorescence was then measured using a Fluoroskan Ascent fluorescence plate reader (ThermoLabsystems). The excitation filter was set at $485 \mathrm{~nm}$ and emission filter at $538 \mathrm{~nm}$. Background fluorescence (no carboxy- $\mathrm{H}_{2}$ DCFDA added) was subtracted and the results normalized to control conditions (carboxy- $\mathrm{H}_{2}$ DCFDA added, but no BMAA exposure).

\section{Results}

\section{Low concentration of BMAA potentiates effects of other neurotoxins}

Previous studies have found that BMAA is neurotoxic both in vivo (Spencer et al., 1987) and in vitro (Ross et al., 1987; Weiss and Choi, 1988; Weiss et al., 1989; Zeevalk and Nicklas, 1989), but that induction of neuronal death by BMAA requires high concentrations. We repeated these studies in cortical cultures and found similar results, with no significant toxicity occurring until a BMAA concentration of 1 $\mathrm{mM}$ (Figure 1). Table 1 shows the effects of BMAA concentrations of 10,50 and $100 \mu \mathrm{M}$, both alone, and in combination with insults that induce low levels of neuronal death. The results indicate that BMAA at

Neurobiology of Disease, Vol. 25, No. 2 (February 2007): pg. 360-366. DOI. This article is @ Elseiver and permission has been granted for this version to appear in e-Publications@Marquette. Elsevier does not grant permission for this article to be further copied/distributed or hosted elsewhere without the express permission from Elsevier. 
these concentrations causes no toxicity by itself, but it does potentiate a number of types of injury. Specifically, at $100 \mu \mathrm{M}$ or less, it potentiated $\mathrm{N}$-methyl-D-aspartate (NMDA), iron (Fe), buthionine sulfoximine (BSO), amyloid- $\beta$, and 1-methyl-4-phenylpyridinium ion $(\mathrm{MPP}+)$ toxicity. The lowest concentration that caused an effect was 10 $\mu M$ BMAA, which caused potentiation of amyloid- $\beta$ and MPP+ toxicity.

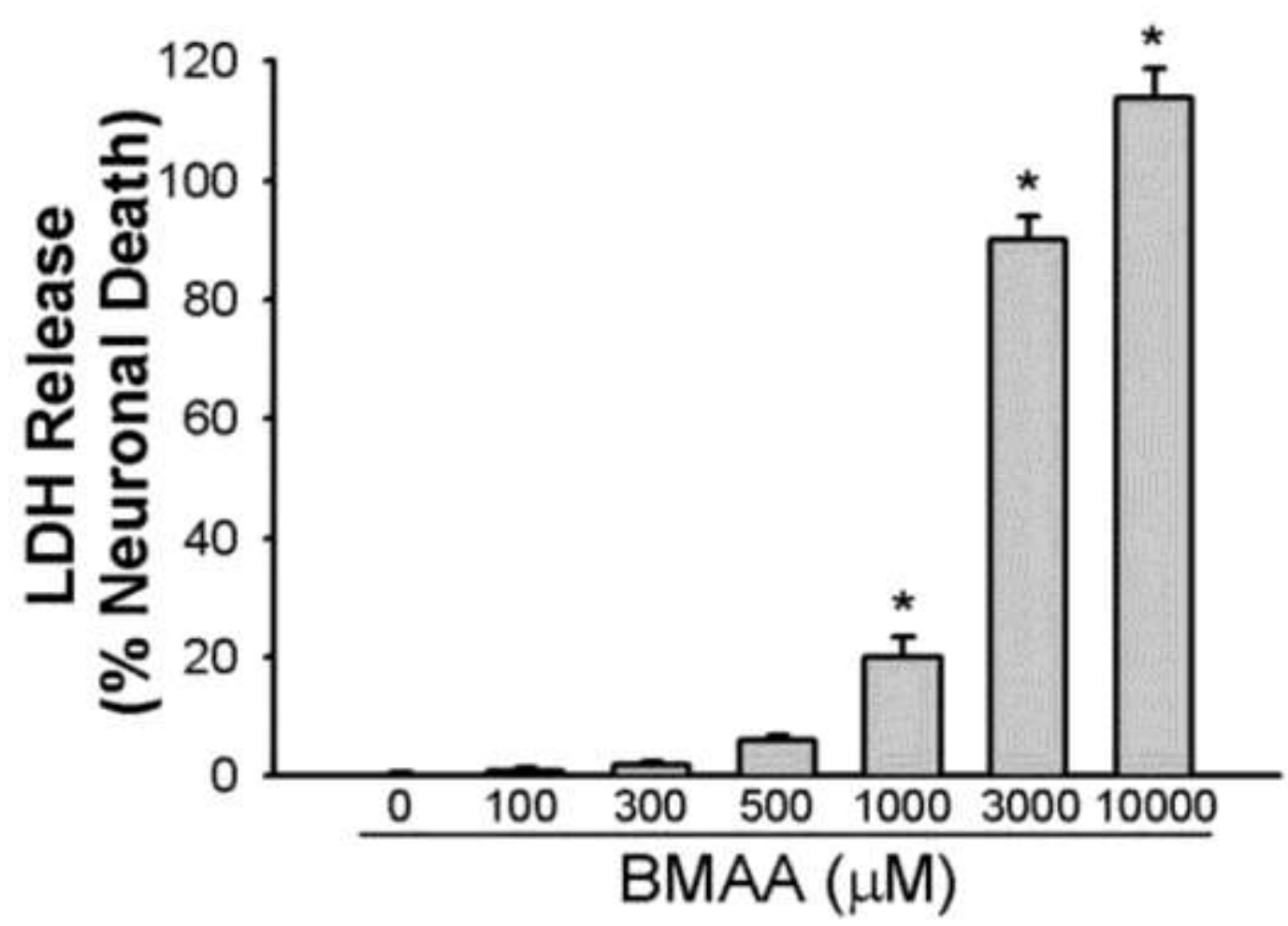

Figure 1 BMAA alone does not induce significant toxicity until a concentration of 1 $\mathrm{mM}$. Bars show \% neuronal cell death (mean $\pm \mathrm{SEM}, \mathrm{n}=8-16$ ) quantified by measuring release of $\mathrm{LDH}, 24 \mathrm{hrs}$ after the beginning of the exposure to BMAA. * indicates significant toxicity, $P<.05$ (one-way ANOVA followed by the Bonferroni ttest).

Neurobiology of Disease, Vol. 25, No. 2 (February 2007): pg. 360-366. DOI. This article is (C) Elseiver and permission has been granted for this version to appear in e-Publications@Marquette. Elsevier does not grant permission for this article to be further copied/distributed or hosted elsewhere without the express permission from Elsevier. 
NOT THE PUBLISHED VERSION; this is the author's final, peer-reviewed manuscript. The published version may be accessed by following the link in the citation at the bottom of the page.

Table 1 Neuronal death induced by exposure of cortical cell cultures to BMAA alone or in combination with another insult.

\begin{tabular}{|c|c|c|c|c|}
\hline & 0 & 10 & 50 & 100 BMAA $(\mu M)$ \\
\hline Insult & & \% Neurona & eath & \\
\hline Control & $0 \pm 1$ & $0 \pm 1$ & $0 \pm 1$ & $1 \pm 1$ \\
\hline NMDA & $6 \pm 2$ & $6 \pm 2$ & $7 \pm 2$ & $26 \pm 6^{*}$ \\
\hline Kainate & $25 \pm 5$ & $23 \pm 2$ & $28 \pm 4$ & $30 \pm 4$ \\
\hline $\mathrm{Fe}$ & $18 \pm 3$ & $19 \pm 3$ & $27 \pm 4$ & $33 \pm 3^{*}$ \\
\hline BSO & $25 \pm 3$ & $34 \pm 6$ & $33 \pm 4$ & $53 \pm 6^{*}$ \\
\hline Amyloid- $\beta$ & $7 \pm 1$ & $13 \pm 1^{*}$ & $18 \pm 2^{*}$ & $21 \pm 2^{*}$ \\
\hline MPP+ & $8 \pm 2$ & $23 \pm 3^{*}$ & $46 \pm 5^{*}$ & $49 \pm 5^{*}$ \\
\hline C-2 ceramide & $24 \pm 2$ & $27 \pm 3$ & $24 \pm 2$ & $20 \pm 2$ \\
\hline Staurosporine & $26 \pm 2$ & $19 \pm 2$ & $18 \pm 2^{*}$ & $21 \pm 2$ \\
\hline
\end{tabular}

Concentrations used were: $5 \mu \mathrm{M}$ NMDA; $30 \mu \mathrm{M}$ kainate; $30 \mu \mathrm{M} \mathrm{Fe}, 250 \mu \mathrm{M}$ BSO; $10 \mu \mathrm{M}$ amyloid- $\beta$ (25-35); $10 \mu \mathrm{M}$ MPP+; $50 \mu \mathrm{M}$ C2-ceramide; $200 \mathrm{nM}$ staurosporine.

Concentrations were chosen to induce low levels of neuronal death allowing potentiation by BMAA to be observed. Data presented as mean \pm SEM $(n=16-24)$ quantified by measuring release of $\mathrm{LDH}, 24$ hours after the beginning of the insult. *indicates significant difference from control injury (insult with no BMAA present), $\mathrm{P}<$ 0.05 (one-way ANOVA followed by the Bonferroni t-test).

\section{$B M A A$ acts on the NMDA receptor}

To determine the mechanism of BMAA effects on neuronal death, we studied the toxicity induced by exposure to 3 mM BMAA. This concentration of BMAA produces near complete neuronal death, allowing for analysis of the toxic actions of BMAA without the confounding effects of other insults. Previous studies have indicated protection against BMAA toxicity by NMDA receptor antagonists (Ross et al., 1987; Weiss et al., 1989). We found that the non-competitive NMDA receptor antagonist MK-801 blocks about 50\% of BMAA toxicity, in contrast to its complete block of NMDA induced toxicity (Fig. 2a). Exposure to either BMAA or NMDA for 1 hour induced increased calcium influx, and the increase in each case was largely blocked by MK-801 (88\% block of BMAA induced ${ }^{45} \mathrm{Ca}^{++}$influx, $96 \%$ block of NMDA induced ${ }^{45} \mathrm{Ca}^{++}$uptake) (Fig. 2b). These results indicate that BMAA can cause death through the NMDA receptor, but since MK-801 only attenuates BMAA toxicity by $50 \%$ other factors are also involved. To determine if the effect of BMAA is a direct effect on the NMDA receptor, we performed whole cell patch-clamp electrophysiology on

Neurobiology of Disease, Vol. 25, No. 2 (February 2007): pg. 360-366. DOI. This article is @ Elseiver and permission has been granted for this version to appear in e-Publications@Marquette. Elsevier does not grant permission for this article to be further copied/distributed or hosted elsewhere without the express permission from Elsevier. 
cultured cortical neurons. BMAA induced a concentration dependent current, with a measurable current first observed at a concentration of $10 \mu \mathrm{M}$ (Fig. 3a,b). The current was largely mediated by activation of NMDA receptors as the competitive NMDA receptor antagonist Damino-5-phosphonovalerate (APV) blocked $94 \%$ of the current induced by $3 \mathrm{mM}$ BMAA (Fig. 3c, d) and provided complete blockade of the current induced by $100 \mu$ M BMAA (data not shown).
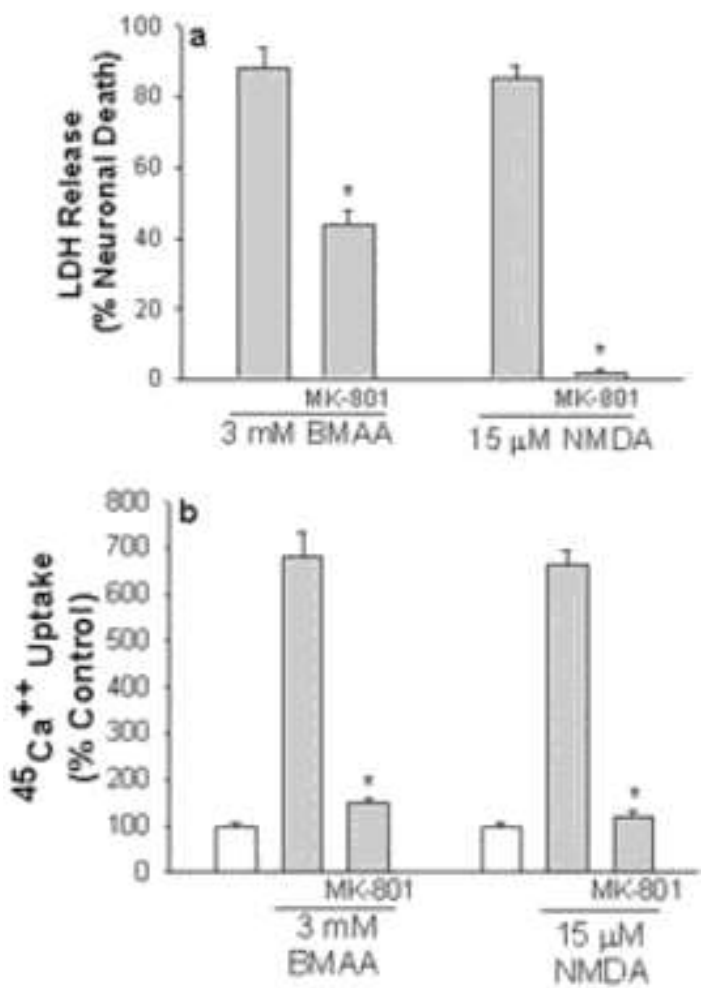

Figure 2 (a) BMAA induced toxicity is partially blocked by the NMDA receptor antagonist MK-801. Concentration used was: $10 \mu \mathrm{M}$ MK801. Bars show \% neuronal cell death (mean \pm s.e.m., $n=12-16$ ) quantified by measuring release of $L D H, 24$ hours after the beginning of the insult. * indicates significant difference from control injury, $P<0.05$ (Student's t-test). BMAA mediated ${ }^{45} \mathrm{Ca}^{++}$uptake is blocked by MK801. (b) ${ }^{45} \mathrm{Ca}^{++}$uptake was measured during a 1 hour exposure to BMAA. Bars show $\%$ control ${ }^{45} \mathrm{Ca}^{++}$uptake (mean \pm s.e.m., $\mathrm{n}=16$ ). * indicates significant difference from BMAA or NMDA alone, $P<0.05$ (Student's t-test).

Neurobiology of Disease, Vol. 25, No. 2 (February 2007): pg. 360-366. DOI. This article is (C) Elseiver and permission has been granted for this version to appear in e-Publications@Marquette. Elsevier does not grant permission for this article to be further copied/distributed or hosted elsewhere without the express permission from Elsevier. 
a

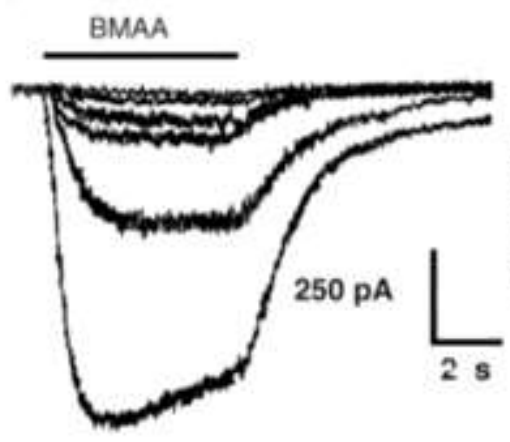

C

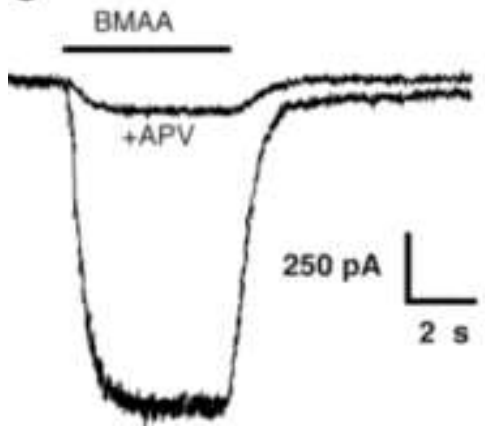

b

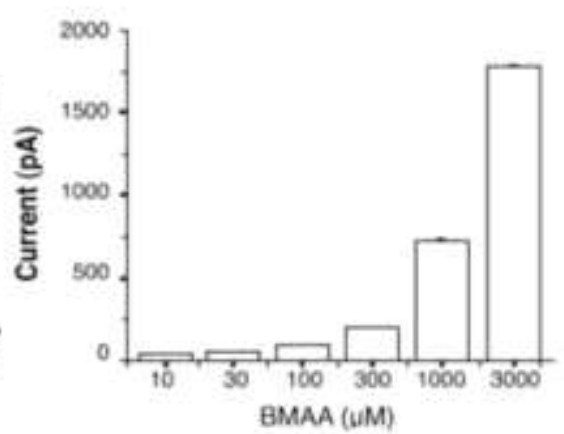

d

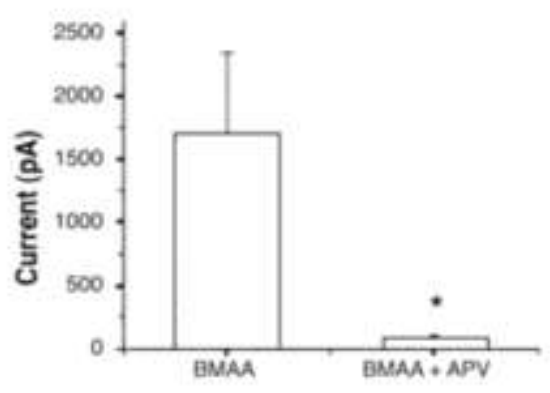

Figure 3 BMAA has NMDA receptor agonist activity in CNS neurons. (a) Current activated by BMAA at various concentrations in a cultured cortical neuron. Concentrations used were: $10-3000 \mu \mathrm{M}$ BMAA, $50 \mu \mathrm{M}$ glycine,. (b) Concentration dependence of BMAA-activated current. Note that concentrations in the low micromolar range elicited measurable currents. (c) Current elicited by the application of BMAA is blocked by the NMDA receptor antagonist APV. Concentrations used were: $3000 \mu \mathrm{M}$ BMAA, $500 \mu \mathrm{M}$ APV. (d) Bars indicate current (mean \pm s.e.m.; $\mathrm{n}=4$ ) activated by $3000 \mu \mathrm{M} \mathrm{BMAA}$, in the absence and presence of $500 \mu \mathrm{M}$ APV. * indicates significant difference from BMAA alone, $P<0.05$ (Mann-Whitney test).

\section{BMAA toxicity involves the NMDA receptor, mGLUR5, and oxidative stress}

As in previous studies we found that blockade of NMDA receptors provides significant protection against high concentration BMAA toxicity (Ross et al., 1987; Weiss et al., 1989). However, as in the previous studies, the protection was not complete, suggesting additional mechanisms of BMAA toxicity. We found two other distinct mechanisms are involved. The mGluR5 receptor antagonist 6-methyl2-[phenylethynyl]-pyridine (MPEP), and the free radical scavenger, trolox, provided additional protection against BMAA toxicity beyond that provided by MK-801 (Fig. 4a). Furthermore, the combination of

Neurobiology of Disease, Vol. 25, No. 2 (February 2007): pg. 360-366. DOI. This article is (C) Elseiver and permission has been granted for this version to appear in e-Publications@Marquette. Elsevier does not grant permission for this article to be further copied/distributed or hosted elsewhere without the express permission from Elsevier. 
these agents provided significantly greater protection then either alone, suggesting that they were acting through distinct mechanisms. Neither compound was protective against BMAA toxicity without MK801 present, likely because of the overwhelming toxicity induced by BMAA activation of the NMDA receptor. No protection beyond that caused by MK-801 was provided by the addition of the mGluR1 receptor antagonist 7-(hydroxyimino)cyclopropa[b] chromen-1Acarboxylate ethyl ester (CPCCOEt), the AMPA/kainate receptor antagonist 6-cyano-7-nitro-quinoxaline-2,3-dione (CNQX), or the nonselective caspase inhibitor Z-Val-Ala-Asp-fluoromethylketone (ZVAD) (data not shown). The protection afforded by trolox suggests that BMAA induces oxidative stress. Therefore, we measured cellular oxidative stress with the fluorescent dye dichlorofluorescein (DCF). Exposure to $3 \mathrm{mM}$ BMAA for 3 hours caused a significant increase in oxidative stress which was not attenuated by MK-801 or MPEP, but was blocked by trolox, with or without the presence of MK-801 (Fig. 4b).
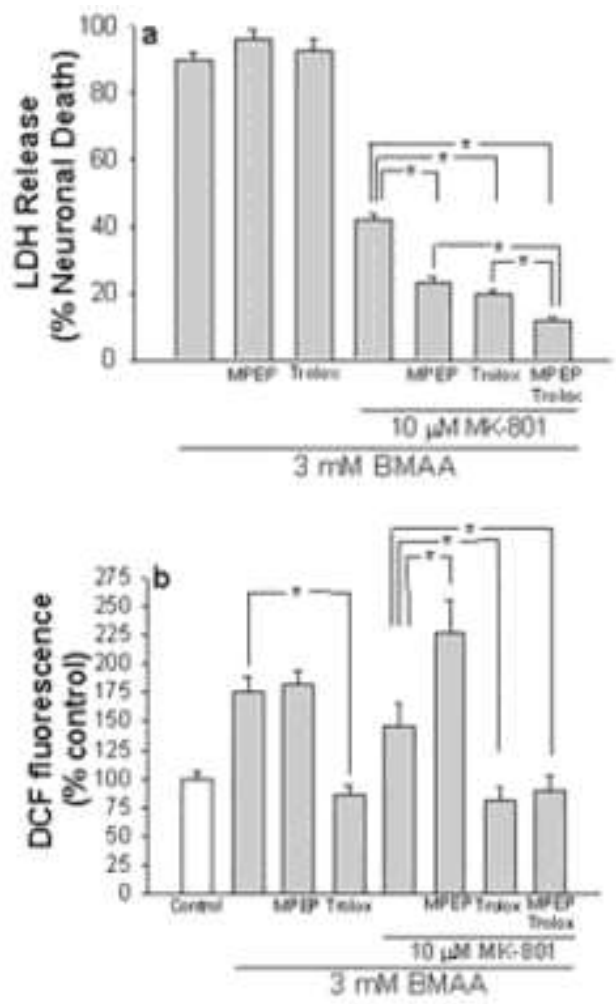

Figure 4 (a) BMAA induced toxicity occurs through multiple mechanisms. Concentrations used were: $10 \mu \mathrm{M}$ MK-801, $50 \mu \mathrm{M}$ MPEP, $100 \mu \mathrm{M}$ trolox. Bars show \% neuronal cell death (mean \pm s.e.m., $n=24-28$ ) quantified by measuring release of 
NOT THE PUBLISHED VERSION; this is the author's final, peer-reviewed manuscript. The published version may be accessed by following the link in the citation at the bottom of the page.

LDH, 24 hrs after the beginning of the insult. * indicates significant difference. (b) BMAA induced oxidative stress is not attenuated by MK-801 or MPEP, but is blocked by trolox. 5-(and -6)-carboxy-2'7'-dichlorodihydrofluorescein diacetate $(10 \mu \mathrm{M})$ was added to the cultures during a 3 hour exposure to BMAA. Bars show $\%$ control fluorescence (mean \pm s.e.m., $\mathrm{n}=24-28$ ). * indicates significant difference, $P<.05$ (one-way ANOVA followed by the Bonferroni t-test).

\section{Discussion}

The present studies provide two important new findings. First, they show that BMAA at concentrations as low as $10 \mu \mathrm{M}$ can potentiate neuronal injury induced by exposure to amyloid- $\beta$ or MPP+. This is the first evidence that BMAA at concentrations below the $\mathrm{mM}$ range can enhance neuronal death in cortical cultures and illustrates an important concept, the potential synergistic effects of environmental toxins with underlying neurological conditions. Second, they show that the mechanism of BMAA toxicity is threefold. It induces toxicity through activation of NMDA and mGluR5 receptors, and it enhances oxidative stress. The mechanism by which BMAA induces oxidative stress was not determined, although it is clear that it is distinct from NMDA and mGluR5 activation as BMAA induced oxidative stress was not blocked by MK-801 or MPEP, and since trolox provided additional protection beyond those agents. One possibility for BMAA-induced oxidative stress is competition by BMAA with cystine at the cystine/glutamate antiporter leading to decreased cystine uptake and depletion of intracellular glutathione. Of interest MPEP in the presence of MK-801 actually caused increased oxidative stress while still being protective. Inhibition of group I mGluRs has been shown previously to enhance oxidative stress (Sagara and Schubert, 1998). The protective effect of MPEP must be through another mechanism, such as inhibition of IP3 production and release of calcium from intracellular stores (Nakamura et al., 2000).

The potentiation of injury by BMAA was selective for certain insults. The type of death induced by the insult, apoptosis or necrosis, does not appear to be the primary determining factor of the effects of BMAA. Exposure to NMDA, Fe, and BSO all induce necrosis in this culture system (Gwag et al., 1997; Lobner et al., 2003), and were potentiated by BMAA. However, kainate also induces necrosis (Gwag et al., 1997), but was unaffected by BMAA. Exposure to C2-ceramide and staurosporine induce apoptosis (Lobner, 2000) and the injury was not

Neurobiology of Disease, Vol. 25, No. 2 (February 2007): pg. 360-366. DOI. This article is @ Elseiver and permission has been granted for this version to appear in e-Publications@Marquette. Elsevier does not grant permission for this article to be further copied/distributed or hosted elsewhere without the express permission from Elsevier. 
enhanced by BMAA (Table 1 ). Amyloid- $\beta$ and MPP+ toxicity have been shown to induce neuronal death with features of both apoptosis and necrosis (Pillot et al., 1999; Han et al., 2003) and the injury in each case was enhanced by BMAA. Amyloid- $\beta$ and MPP+ are of particular importance in that amyloid- $\beta$ toxicity is considered to be a model of Alzheimer's disease (Gotx et al., 2004) and MPP+ of Parkinson's disease (Gerlach and Riederer, 1996). The common point for BMAA potentiation of these injuries may be that amyloid- $\beta$ (Kwon et al., 2004) and MPP+ (Johannessen et al., 1986) are known to induce oxidative stress, as do exposure to NMDA, Fe, and BSO (Dugan et al., 1995; Lobner et al., 2003).

The importance of the results of BMAA potentiation of specific insults is that it shows that BMAA at concentrations 100 fold lower than previously shown can enhance death of cortical neurons. A recent report has shown that BMAA concentrations as low as $30 \mu \mathrm{M}$ can cause selective death of motor neurons (Rao et al., 2006). This study suggests that in contrast to cortical neurons, motor neurons are highly susceptible to BMAA toxicity even without an additional insult. The change made in the current studies is that the effects of BMAA were tested on low level injury induced by an additional insult as opposed to only direct BMAA toxicity. The implication of these studies is that while low level BMAA may not be the sole cause of neurological diseases, it may be able to combine with underlying pathologies to either induce expression of the disease or quicken its progression. An additional factor to be considered is that the current studies represent effects of BMAA over only a brief period of time ( 24 hours) in contrast to the long-term exposure that appears to be involved in the development of ALS/PDC. It seems likely that even lower concentrations of BMAA over such long periods of exposure could enhance neuronal death. The concentration of BMAA found in brain tissues of people who died of ALS/PDC on Guam and Alzheimer's disease in Canada was approximately $6 \mu \mathrm{g} / \mathrm{g}$ (Cox et al., 2003). Unfortunately, an exact correlation between the concentrations of BMAA used in these studies and those found in the brain is not possible because it is not known what concentration of BMAA occurs in the extracellular space surrounding neurons in the brain following BMAA consumption. Previous studies in mice have indicated that administration of BMAA does not induce neurological deficits or neuronal death in vivo (Perry et al., 1989; Cruz-Aguado et al., 2006). These results are not 
inconsistent with the current study. Our results suggest that BMAA alone is unlikely to cause neurological deficits unless very high concentrations are consumed, but that the combination of low levels of BMAA consumption plus another insult may lead to the development of neurological diseases. For example, while feeding mice low levels of BMAA does not induce neurological deficits, feeding BMAA to mice genetically altered to develop neurodegenerative diseases may alter the onset or progression of the disease.

While it has been shown previously that BMAA activates the NMDA receptor (Ross et al., 1987; Weiss and Choi, 1988; Brownson et al., 2002), the electrophysiology studies involving BMAA provide a couple of interesting insights. The BMAA-induced current occurred even under conditions of saturating glycine, suggesting the effect is due to an action at the NMDA binding site and not the glycine binding site. The fact that BMAA induces a significant current even at low concentrations, along with the protection of MK-801 against high concentration BMAA toxicity, suggests that the potentiation of NMDA toxicity is due to a direct action of BMAA on the NMDA receptor.

The importance of the multiple mechanisms of BMAA toxicity shown in the current studies is that this may partially account for the different types of neurological diseases that have been associated with BMAA consumption. It is possible that the different actions of BMAA, in association with varying underlying conditions, may lead to the multiple disorders. Most neurodegenerative diseases appear to involve NMDA receptor mediated excitotoxicity (Lipton, 2004) and oxidative stress (Cui et al., 2004), and mGluR5 receptor activation has been implicated in Parkinson's disease (Marino et al., 2003). Therefore, it is possible that BMAA may enhance the injury occurring during neurodegenerative diseases, and in this way hasten the onset, or increase the progression, of these diseases. 
NOT THE PUBLISHED VERSION; this is the author's final, peer-reviewed manuscript. The published version may be accessed by following the link in the citation at the bottom of the page.

\section{Acknowledgements}

This work was supported by National Institute on Aging Grant AG16798 to D.L.

\section{Footnotes}

Publisher's Disclaimer: This is a PDF file of an unedited manuscript that has been accepted for publication. As a service to our customers we are providing this early version of the manuscript. The manuscript will undergo copyediting, typesetting, and review of the resulting proof before it is published in its final citable form. Please note that during the production process errors may be discovered which could affect the content, and all legal disclaimers that apply to the journal pertain.

\section{References}

1. Brownson DM, Marby TJ, Leslie SW. The cycad neurotoxic amino acid, beta-N-methylamino-L-alanine (BMAA), elevates intracellular calcium levels in dissociated rat brain cells. J. Ethnopharmacol. 2002;82:159167.

2. Cox PA, Sacks OW. Cycad neurotoxins, consumption of flying foxes, and ALS-PDC disease in Guam. Neurology. 2002;58:956-959.

3. Cox PA, Banack SA, Murch SJ. Biomagnification of cyanobacterial neurotoxins and neurodegenerative disease among the Chamorro people of Guam. Proc. Natl. Acad. Sci. U. S. A. 2003;100:1338013383.

4. Cox PA, Banack SA, Murch SJ, Rasmussen U, Tien G, Bidigare RR, Metcalf JS, Morrison LF, Codd GA, Bergman B. Diverse taxa of cyanobacteria produce beta-N-methylamino-L-alanine, a neurotoxic amino acid. Proc. Natl. Acad. Sci. U. S. A. 2005;102:5074-5078.

5. Cui K, Luo X, Xu K, Ven Murthy MR. Role of oxidative stress in neurodegeneration: recent developments in assay methods for oxidative stress and nutraceutical antioxidants. Prog. NeuroPsychopharmacol. Biol. Psychiatry. 2004;28:771-799.

6. Cruz-Aguado R, Winkler D, Shaw CA. Lack of behavioral and neuropathological effects of dietary beta-methylamino-alanine (BMAA) in mice. Pharmacol. Biochem. Behav. 2006 (Epub ahead of print).

Neurobiology of Disease, Vol. 25, No. 2 (February 2007): pg. 360-366. DOI. This article is @ Elseiver and permission has been granted for this version to appear in e-Publications@Marquette. Elsevier does not grant permission for this article to be further copied/distributed or hosted elsewhere without the express permission from Elsevier. 
NOT THE PUBLISHED VERSION; this is the author's final, peer-reviewed manuscript. The published version may be accessed by following the link in the citation at the bottom of the page.

7. Dugan LL, Sensi SL, Canzoniero LM, Handran SD, Rothman SM, Lin TS, Goldberg MP, Choi DW. Mitochondrial production of reactive oxygen species in cortical neurons following exposure to N-methyl-Daspartate. J. Neurosci. 1995;15:6377-6388.

8. Dugan LL, Turetsky DM, Du C, Lobner D, Wheeler M, Almli CR, Shen CK, Luh TY, Choi DW, Lin TS. Carboxyfullerenes as neuroprotective agents. Proc. Natl. Acad. Sci. U.S.A. 1997;94:9434-9439.

9. Duncan WJ, Steele I, Kopin P, Markey SP. 2-Amino-3-(methylamino)propanoic acid (BMAA) in cycad flour: an unlikely cause of amyotrophic lateral sclerosis and parkinsonism-dementia of Guam. Neurology. $1990 ; 40: 767-772$.

10. Gerlach M, Riederer P. Animal models of Parkinson's disease: an empirical comparison with the phenomenology of the disease in man. J. Neural Transm. 1996;103:987-1041.

11. Gotz J, Schild A, Hoerndli F, Pennanen L. Amyloid-induced neurofibrillary tangle formation in Alzheimer's disease: insight from transgenic mouse and tissue-culture models. Int. J. Dev. Neurosci. 2004;11:453-465.

12. Gwag BJ, Koh JY, DeMaro JA, Ying HS, Jacquin M, Choi DW. Slowly triggered excitotoxicity occurs by necrosis in cortical cultures. Neuroscience. 1997;77:393-401.

13. Han BS, Noh JS, Gwag BJ, Oh YJ. A distinct death mechanism is induced by 1-methyl-4-phenylpyridinium or by 6-hydroxydopamine in cultured rat cortical neurons: degradation and dephosphorylation of tau. Neurosci. Lett. 2003;341:99-102.

14. Hartley DM, Kurth MC, Bjerkness L, Weiss JH, Choi DW. Glutamate receptor-induced $45 \mathrm{Ca} 2+$ accumulation in cortical cell culture correlates with subsequent neuronal degeneration. J. Neurosci. 1993;131:1993-2000.

15. Ince PG, Codd GA. Return of the cycad hypothesis - does the amyotrophic lateral sclerosis/parkinsonism dementia complex (ALS/PDC) of Guam have new implications for global health? Neuropath. Appl. Neurobiol. $2005 ; 31: 345-353$.

Neurobiology of Disease, Vol. 25, No. 2 (February 2007): pg. 360-366. DOI. This article is @ Elseiver and permission has been granted for this version to appear in e-Publications@Marquette. Elsevier does not grant permission for this article to be further copied/distributed or hosted elsewhere without the express permission from Elsevier. 
NOT THE PUBLISHED VERSION; this is the author's final, peer-reviewed manuscript. The published version may be accessed by following the link in the citation at the bottom of the page.

16. Johannessen JN, Adams JD, Schuller HM, Bacon JP, Markey SP. 1-Methyl4-phenylpyridine (MPP+) induces oxidative stress in the rodent. Life Sci. 1986;38:743-749.

17. Koh JY, Choi DW. Quantitative determination of glutamate mediated cortical neuronal injury in cell culture by lactate dehydrogenase efflux assay. J. Neurosci. Methods. 1987;20:2083-2090.

18. Kwon YS, Koh JY, Song DK, Kim HC, Kwon MS, Choi YS, Wie MB. Danthron inhibits the neurotoxicity induced by various compounds causing oxidative damages including beta-amyloid (25-35) in primary cortical cultures. Biol. Pharm. Bull. 2004;27:723-726.

19. Lipton SA. Failures and successes of NMDA receptor antagonists: molecular basis for the use of open-channel blockers like memantine in the treatment of acute and chronic neurologic insults. NeuroRx. 2004; $1: 101-110$.

20. Lobner D. Comparison of the LDH and MTT assays for quantifying cell death: validity for neuronal apoptosis? J. Neurosci. Methods. 2000;96:147-152.

21. Lobner D, Golner S, Hjelmhaug J. Neurotrophic factor effects on oxidative stress-induced neuronal death. Neurochem. Res. 2003;28:749-756.

22. Marino MJ, Valenti O, Conn PJ. Glutamate receptors and Parkinson's disease: opportunities for intervention. Drugs Aging. 2003;20:377397.

23. Montine TJ, Ke L, Perl DP, Galasko D. Lack of beta-methylamino-I-alanine in brain from controls, AD, or Chamorros with PDC. Neurology. 2005;65:768-769.

24. Murch SJ, Cox PA, Banack SA. A mechanism for slow release of biomagnified cyanobacterial neurotoxins and neurodegenerative disease in Guam. Proc. Natl. Acad. Sci. U. S. A. 2004;101:1222812231.

25. Nakamura T, Nakamura K, Lasser-Ross N, Barbara JG, Sandler VM, Ross WN. Inositol 1,4,5-trisphosphate (IP3)-mediated Ca2+ release evoked by metabotropic agonists and backpropagating action potentials in hippocampal CA1 pyramidal neurons. J. Neurosci. 2000;20:83658376.

Neurobiology of Disease, Vol. 25, No. 2 (February 2007): pg. 360-366. DOI. This article is @ Elseiver and permission has been granted for this version to appear in e-Publications@Marquette. Elsevier does not grant permission for this article to be further copied/distributed or hosted elsewhere without the express permission from Elsevier. 
NOT THE PUBLISHED VERSION; this is the author's final, peer-reviewed manuscript. The published version may be accessed by following the link in the citation at the bottom of the page.

26. Perl TM, Bedard L, Kosatsky T, Hockin JC, Todd EC, Remis RS. An outbreak of toxic encephalopathy caused by eating mussels contaminated with domoic acid. N. Engl. J. Med. 1990;322:17751780 .

27 .Perry TL, Bergeron C, Biro AJ, Hansen S. Beta-N-methylamino-L-alanine. Chronic oral administration in not neurotoxic to mice. J. Neurol. Sci. $1989 ; 94: 173-180$.

28. Pillot T, Drouet B, Queille S, Labeur C, Vandekerchkhove J, Rosseneu M, Pincon-Raymond $\mathrm{M}$, Chambaz J. The nonfibrillar amyloid beta-peptide induces apoptotic neuronal cell death: involvement of its C-terminal fusogenic domain. J. Neurochem. 1999;73:1626-1634.

29. Rao SD, Banack SA, Cox PA, Weiss JH. BMAA selectively injures motor neurons via AMPA/kainate receptor activation. Exp. Neurol. 2006 (Epub ahead of print).

30. Ren $\mathrm{H}$, Honse $\mathrm{Y}$, Peoples RW. A site of alcohol action in the fourth membrane-associated domain of the $\mathrm{N}$-methyl-D-aspartate receptor. J. Biol. Chem. 2003;278:48815-48820.

31. Rosenthal GA. The biological effects and mode of action of L-canavanine, a structural analogue of L-arginine. Q Rev. Biol. 1977;52:155-178.

32. Ross SM, Seelig M, Spencer PS. Specific antagonism of excitotoxic action of 'uncommon' amino acids assayed in organotypic mouse cortical cultures. Brain Res. 1987;425:120-127.

33. Sagara $Y$, Schubert D. The activation of metabotropic glutamate receptors protects nerve cells from oxidative stress. J. Neurosci. 1998;18:66626671.

34. Spencer PS, Nunn PB, Hugon J, Ludolph AC, Ross SM, Roy DN, Robertson RC. Guam amyotrophic lateral sclerosis-parkinsonism-dementia linked to a plant excitant neurotoxin. Science. 1987;237:517-522.

35. Wang $\mathrm{H}$, Joseph JA. Quantifying cellular oxidative stress by dichlorofluorescein assay using microplate reader. Free Radical Biol. Med. $1999 ; 27: 612-616$.

Neurobiology of Disease, Vol. 25, No. 2 (February 2007): pg. 360-366. DOI. This article is @ Elseiver and permission has been granted for this version to appear in e-Publications@Marquette. Elsevier does not grant permission for this article to be further copied/distributed or hosted elsewhere without the express permission from Elsevier. 
NOT THE PUBLISHED VERSION; this is the author's final, peer-reviewed manuscript. The published version may be accessed by following the link in the citation at the bottom of the page.

36. Weiss JH, Choi DW. Beta-N-methylamino-L-alanine neurotoxicity: requirement for bicarbonate as a cofactor. Science. 1988;241:973975.

37. Weiss JH, Koh JY, Choi DW. Neurotoxicity of beta-N-methylamino-Lalanine (BMAA) and beta-N-oxalylamino-L-alanine (BOAA) on cultured cortical neurons. Brain Res. 1989;497:64-71.

38. Yin KJ, Hsu CY, Hum XY, Chen $\mathrm{H}$, Chen SW, Xu J, Lee JM. Protein phosphatase $2 \mathrm{~A}$ regulates bim expression via the Akt/FKHRL1 signalling pathway in amyloid-beta peptide-induced cerebrovascular endothelial cell death. J. Neurosci. 2006;26:2290-2299.

39. Zeevalk GD, Nicklas WJ. Acute excitotoxicity in chick retina caused by the unusual amino acids BOAA and BMAA: effects of MK-801 and kynurenate. Neurosci. Lett. 1989;102:284-290.

Corresponding Author: Doug Lobner, Department of Biomedical Sciences, Marquette University, 561 N. $15^{\text {th }}$ Street, Rm 426, Milwaukee, WI 53233, Tel: 414-288-6569, Fax: 414-288-6564, Email: doug.lobner@marquette.edu 